\title{
THE IRISH REFERENDUM ON THE TREATY OF NICE AND ARTICLE 10 EC A Recent Example of The Constitutional Problems of Enlargement
}

\author{
Alfred E. Kellermann*
}

\section{Abstract}

This article views the Irish referendum on the Treaty of Nice as an example of the constitutional problems of enlargement. The article addresses whether Article 10 EC applies for national and European constitutional ratification provisions and suggests legal and political solutions for the constitutional problems in the Irish case.

The Irish referendum on the Treaty of Nice is a recent example of the importance of national constitutions and its impact on enlargement. The Nice Treaty was concluded by the Representatives of the Member States of the EU, meeting within the European Council held in Nice in December 2000. By common accord they agreed to amend the Treaty on European Union, the Treaties establishing the European Communities and certain related acts. According to Article 48 Treaty on European Union (TEU), the amendments will enter into force after being ratified by all the Member States in accordance with their respective constitutional requirements. In Ireland one of the constitutional requirements for the ratification of a treaty is to hold a referendum. The result of the referendum held on Thursday 7 June 2001 not to ratify the Nice Treaty (the actual percentages were: YES 46,13\%, NO $53,87 \%$ ), does raise several political and constitutional questions for legal solutions that would finally allow for the ratification of the treaty. It is however not for the first time that referenda form obstacles for the ratification of an European Treaty. There was a near failure to have the Maastricht Treaty ratified in Denmark and in France. In Norway accession

"General Secretary of the T.M.C. Assen Institute, The Hague, The Netherlands. 
was rejected twice in referenda, the first time in 1973 and the second time in 1994. The Agreement on the European Economic Area was rejected in a subsequent national referendum in Switzerland in 1992.

In the following we like to give some suggestions as a contribution to an exchange of ideas to the finding of legal and political solutions for these constitutional problems focusing on the recent Irish referendum..

The Irish complaints against the Nice Treaty were quite varied, reflecting everything from fears over loss of influence in an enlarged EU to concerns that the EU's military plans might threaten Ireland's traditional neutrality. The reasons for the NO vote had not only to do with enlargement, but to a large extent reflected disenchantment with further integration, which has been foisted on an unwilling electorate by political elites. The referendum culture in Ireland is very strong and, due to a series of political funding scandals, there is a deep cynicism towards politicians. Moreover, the electorate were assured in 1972 that with each significant step towards integration that there would be a referendum. The next move for Ireland is unclear. Its EU partners have already ruled out a complete renegotiation of the complex treaty. The alternative is a political declaration attached to the treaty which seeks to meet Irish concerns. ${ }^{1}$

One of the central questions to be answered from an European law point of view is whether the Irish Government complied with the duty of loyalty to the Community as mentioned in Article 10 EC Treaty. Article 10 EC reads as follows:

"Member States shall take all appropriate measures, whether general or particular, to ensure fulfilment of the obligations arising out of this Treaty or resulting from action taken by the institutions of the Community. They shall facilitate the achievement of the Community's tasks. They shall abstain from any measure which could jeopardise the attainment of the objectives of this Treaty."

The principal and essential question which arises is whether Article 10 EC applies at all for national and european constitutional ratification provisions? 
The first point concerns the implementation of the procedure and Article 10 EC. The second point concerns the adaptation of the national constitutional provisions.

Can the ratification provisions of Article 48 TEU jo. Article 313 (EC Treaty) be considered as obligations arising out of the EU and EC Treaty as required in the wording of Article 10 EC Treaty; Or can these obligations only be considered as obligations arising out of international law after signing a treaty according to the 1969 Vienna Convention on the Law of the Treaties?

Do the implementation of the national constitutional ratification provisions of Article 48 TEU jo. Article 313 (EC Treaty) also have to comply with the criteria of Article $10 \mathrm{EC}$ ? In other words if the national constitutional provisions in theory would be a serious obstacle for the ratification of a Treaty amendment, would Member States then be obliged according to Article $10 \mathrm{EC}$ to adapt the national constitutional provivions.

National constitutional lawyers argue that Article $10 \mathrm{EC}$ will only apply to existing Treaty obligations which will enter into force only after ratification. Would it not be possible, as the European Court of Justice has done in some earlier cases, to give a teleological interpretation also to the provisions of Article 313 EC Treaty ("This Treaty shall be ratified by the High Contracting Parties.....") so that these provisions can be considered as a community obligation of loyalty in the meaning of Article $10 \mathrm{EC}$ ?

Perhaps a teleological interpretation of these articles may enlarge the applicability of Article $10 \mathrm{EC}$ to agreements concluded in unanimity by all the governments meeting within the European Council. Would it not be possible to interpret these agreements as decisions of the representatives of the governments of the member states meeting within the Council? These acts or decisions have generally a character of international law, but may in certain cases form part of Community law and as such they are not subject to any rules of national constitutional law on the conclusion of international agreements. $^{2}$

If the answer is in the affirmative and if therefore Article $10 \mathrm{EC}$ or its principles do apply, the question may arise whether it would have been possible for the Irish Government to avoid all the problems of the NO vote. 
Was it wise to hold a referendum for treaty amendments? Was the Irish Government guilty of not informing the Irish people satisfactorily about the objectives of the Treaty of Nice and of not stimulating enough YES votes? If that were the case, then the Irish Government is responsible for the delay in ratification. As mentioned in the Financial Times of 14 June 2001, Brian Cowen, the Irish foreign minister, indicated there would be no early move to put a new referendum to the people to reverse the decision rejecting the Nice Treaty on enlargement of the European Union.

Although it is in accordance with the principle of subsidiarity, the differences in the constitutional requirements between the Member States for the ratification of treaties may lead to bad results for European integration if the objectives of the proposed referenda are not sufficiently achieved by some governments of the Member States. Given the importance of the outcome of the referendum, should the Irish Government, which after all signed the Treaty of Nice, not have indicated that it would resign in the case of a NO vote?

On the one hand, it is constitutionally advisable to hold a referendum in order to comply with the requirement of Article 6 TEU which refers to the principles of democracy on which the Union is based; on the other hand, this case shows that using referenda for amendment procedures of rather complicated treaties is not always an efficient procedure and may result in unexpected and unpleasant outcomes for further European integration.

Assuming that Article $10 \mathrm{EC}$ or its principles will more or less apply in this Irish case, a short comment on the interpretation of its provisions and reference to some ECJ Decisions may be useful.

In its present wording Article $10 \mathrm{EC}$ refers only to the relationship between the Community and its Member States and is formulated, moreover, as if it were a one-way-street, that is as a duty imposed on the Member States to take all measures to promote the Community interests... ${ }^{3}$. The Community interests are in this case the speedy ratification of the Nice Treaty by all the Member States.

The notion of "Member State" is a global and wide one. It covers not only the central authorities, the "executive" (the central Government), but also the local and/or regional authorities of a Member State. ${ }^{4}$ 
Where clear breaches of Community law are at hand, as in violating the prohibition against discrimination, the Court is not impressed, generally speaking, by a Member States invoking constitutional provisions to justify such a breach. A number of examples illustrate this attitude. ${ }^{5}$

A Member State cannot rely upon provisions of its Constitution for the purpose of justifying a failure to comply with obligations and time-limits resulting from directives. ${ }^{6}$

According to the opinion of de Zwaan, Article 10 EC encompasses an obligation of a general and broad, but not very precise, character. Thus although its merits and importance have only been increasing over the years, also in the jurisprudence of the Court of Justice, the significance of Article $10 \mathrm{EC}$ in the context of the present discussion is to be seen as the reflection of a general attitude to be expected from an average and loyal Member State rather than serving as a basis to impose specific and concrete conduct on the State concerned. It may be considered as a source of inspiration for the national judiciary, nothing less but also nothing more. ${ }^{7}$ In our opinion, it may be also considered as a source of inspiration for the national governments.

From all the above-mentioned considerations, we may conclude and suggest the following two legal and political solutions for the constitutional problems in the Irish case.

In the first place, in our opinion Article $10 \mathrm{EC}$ may be also considered as a source of inspiration for the Irish Government to "take all appropriate measures, whether general or particular, to ensure fulfilment of the obligations arising out of this Treaty or resulting from action taken by the institutions of the Community... " to improve the support of the Irish people for its government policies and stimulate greater participation of the Irish people at these referenda. In this situation a more succesful and government friendly outcome of referenda may be expected.

In the second place, Article $10 \mathrm{EC} \mathrm{(...They} \mathrm{shall} \mathrm{abstain} \mathrm{from} \mathrm{any}$ measure which could jeopardise the attainment of the objectives of this Treaty") may inspire the Irish Government to propose to its electorate an amendment of its constitution for example by proposing for some cases a 
replacement in the Constitution of referenda by a parliamentary procedure if this would improve the attainment of the objectives of the Treaty, especially for complicated treaties. As such texts are not easy to understand by ordinary Irish people, it seems better to submit these texts to members of parliament who may consult their legal staff. The text of the Treaty on European Union of 1991 was already very complicated, and the text of the Treaty on European Union after the Amsterdam amendment is still more inaccessible and difficult to consult because of the insertion of many new Articles, Protocols and Declarations and the renumbering of the Consolidated Treaty text. $^{8} \quad$ The text of the Treaty after Nice is even more inaccessible, complicated and difficult to understand. It was therefore to be expected that the ordinary people of Ireland might say $\mathrm{NO}$ in a Referendum to a text which they did not understand, except perhaps if they were experts in European law!

\section{Endnotes}

${ }^{1}$ John Murray Brown, Financial Times, June 12, 2001,

${ }^{2}$ P.J.G.Kapteyn and Verloren van Themaat, Introduction to the Law of the European Communities, Third Edition, 1998 p.341, Edited by Laurence W. Gormley, Kluwer Law International

${ }^{3}$ Report of the XIX F.I.D.E. Congress, Helsinki 1 - 3 June 2000, p 9, W. van Gerven

${ }^{4}$ Report of the XIX F.I.D.E. Congress, Helsinki 1 - 3 June 2000, p. 229 , Jaap W. de Zwaan, Idem Tijdschrift voor Europees en Economisch recht (SEW), 48e jaargang no.4 april 2000, p. 132 - 154, Jaap W. de Zwaan

${ }^{5}$ ECJ Court Decisions Case 77/69 Commission v. Belgium (1970 ECR 237, para 15 and several judgments of 2 February 1982 of the ECJ in cases of the Commission v.Belgian. See Jan Wouters - "National Constitutions and the European Union" Legal Issues of Economic Integration, Volume 27, 2000 I, p.56 and 57 notes 127 and 128.

${ }^{6}$ ECJ Case 100/77 Commission v. Italy (1978) ECR 887, par.21. See Lenaerts/van Nuffel Constitutional Law of the European Union, Sweet \& Maxwell, London, 1999, p.574 and 575. 
${ }^{7}$ supra note no.2, p. 247 and SEW, p. 146

${ }^{8}$ See "Improving the Quality of Legislation in Europe", T.M.C. Asser Instituut, Kluwer Law International, Editors Alfred E. Kellermann et.al., The Hague. 1998, Report of the Conference, p.. XXXV and XXXVI. 